\title{
THE EFFECTIVENESS OF USING EDMODO TO TEACH WRITING ANALYTICAL EXPOSTION TEXT AT THE ELEVENTH GRADE OF SMA NEGERI 1 GROGOL
}

\author{
Nanda Adhnan Arif Nugraha, Erwin Hari Kurniawan
}

\begin{abstract}
Edmodo is a proper Learning Management System (LMS) in teaching writing. Edmodo was chosen because the features of Edmodo can help students to write their ideas. This research was intended to know the effectiveness of using Edmodo to teach writing analytical exposition text. this research used quantitative approach, while the design used was posttest-only control group design. In this research used two classes, there are experimental group and control group. In the experimental group used Edmodo, and in the control group was taught using conventional teaching. To collect the data, post writing test in experimental and control group were administered. Data were analyzed by using mean scores, standard deviation, and independent sample t-test. In result of this research showed that $\mathrm{p}$ value was lower than alpha value. It can be concluded that using Edmodo to teach writing analytical exposition is effective.
\end{abstract}

Keywords: analytical exposition text, Edmodo, learning management system, writing,

\section{INTRODUCTION}

Writing is one of the important skills that should be mastered by students. Anggrayani (2015: 2) states that writing refers to the ability to express the author's opinion clearly and effectively in written form. Writing is a communication tool by putting thoughts, ideas, opinion, or experiences in written form (Larasanti \& Marlina, 2019: 1). As a communication tool, writing is a media

to express ideas and emotional feelings, because when they write their ideas and emotion creatively, they are communicating on papers in their best way and purposes (Azzahara \& Supiatman, 2018: 1). Based on that explanation, it can be concluded that writing skill is an important part of communication where the writer can deliver his / her opinion and thoughts to the readers. Good writing skill allows us to communicate our message with clarity and ease to a far large audience through face-to-face or telephone conversation. To produce a good writing, there is a series of writing process that the writer should follow since beginning until the end. Since writing is an important skill of English, it is clear that people need to learn writing.

Analytical exposition is one of the compulsory texts which is taught in Senior High School in Indonesia, especially at the eleventh grade. According to Sari (2017: 50), analytical exposition text is a text that tells the readers or listeners about something in the case. Its function of this text is to persuade readers' or 
listeners' mind about something is exceptionally to be discussed. After learning analytical exposition text, students are hoped be able to compose and write analytical exposition (Irwan et al, 2018: 170). To make good analytical exposition text, the students must understand the issue to that happens currently and have the good writing ability.

As stated above, Senior High School students must be able to communicate well in the spoken and written form, include communicate through writing analytical exposition text. Unfortunately, in Indonesia not all of the students are able to produce good writing of analytical exposition text. Students face some problems in writing analytical exposition text because there are some aspects of writing that make them think that writing is a difficult skill. That aspects related with students' vocabulary mastery, students' grammar knowledge, students understanding or text organization, and so on. Moreover, English is not students' first language. Students do not use English in their daily conversation. That makes them have some problems when they try to write their ideas. In addition, Nuraeni (2016: 489) mentions that students cannot write their ideas because they do not understand with the goal of their writing. This condition makes students do not want to write English text. Besides that, the researcher has observed of the teaching and learning process of English language, and it is found that the appropriate media and the source of material have not been utilized maximally. It makes the students difficult to generate and organize their ideas by using correct vocabulary, tenses, and develop ides into coherence text.

To solve the problem in teaching writing analytical exposition, the teacher should find out useful things as teaching aids to make the students enjoy and active in the class, in this era teacher using laptop, tablet, and smartphone. Many people agree that laptop, tablet, and smartphone are essential tools for our daily lives. Now students always bring their smartphone wherever they go. The teacher can take advantages of this situation by utilizing student's mobile phone to learn English, especially writing analytical exposition text. It is related with one current issue in the field of education, that is the existence of Learning Management System (LMS). LMS is an integrated set of software that allows the administration, tracking, reporting, documentation, and delivery of e-learning courses or distance education programs (Arpaci, 2017: 54). From that that definition, it can be concluded that LMS is an educational website or application that support teaching and learning process.

One of Learning Management System that has many benefits in education field is Edmodo (Essa, 2018: 16). Edmodo is a social-network-based learning platform intended for educational practitioner, such as teacher, students, and parents (Sumarno, 2018: 101). At Edmodo teacher can send quiz, and assignment to the students, provide feedback, collect completed assignment, assign graders, save and share informational content in file or link, conduct polls, and send notes and text alerts to individual pupils or to the whole class (Essa, 2018: 17). Edmodo looks similar with Facebook, but it is more private and safe for a learning environment (Majid, as cited in Diantari et al, 2018: 4). It is accessible through mobile phone application (Sumarno \& Tatik, 2018: 101) and the site www.Edmodo.com (Yusuf et al, 2018: 335). To maximize the use of Edmodo to 
helps students to improve their writing skill, this research uses blended learning that can be applied by using Edmodo. Blended learning is a method that combines face-to-face and online learning. Sometimes students cannot understand the material when they do face-to-face learning, so online learning is an alternative way to help them to improve their comprehension. This method is hoped to give positive impact to students' writing skill in writing analytical exposition text.

Based on that explanation, the researcher would like to find out the effectiveness of using Edmodo to teach writing analytical exposition.

The study intends to answer the following questions: (1) How is the eleventh graders skill of writing analytical exposition text in treatment class after taught by using Edmodo (2) How is the eleventh graders skill of writing analytical exposition text in conventional class after taught by using conventional learning way (3) Is there any significant difference of writing skill of analytical exposition text between the conventional class and treatment class (4) Is Edmodo effective to be used to teach writing analytical exposition text at the eleventh grade of SMAN 1 Grogol.

\section{RESEARCH METHOD}

Design of this research was quantitative research that intended to find out the effectiveness of using Edmodo to teach writing analytical exposition text at the eleventh grade of SMAN 1 Grogol. . Quantitative research is The design of this research was experimental, especially quasi experimental design with posttest only control group design. After teacher finished teaching in experimental and control class, post-test was given to those classes. Post-test was done to know the effectiveness of using Edmodo to teach writing analytical exposition text.

This research was done at SMAN 1 Grogol. It is located at Jl. Raya Gringging 16 Sonorejo, Grogol, Kediri. The Subject of this research was students of eleventh grade at SMAN 1 Grogol. There were 10 classes of eleventh grade at SMAN 1 Grogol, but the researcher could not do the research in all classes because of the time limitation. The researcher selected two classes randomly as the sample of all students in eleventh grade. The chosen classes were XI MIA 2 and XI MIA 3. XI MIA 2 was experimental class, while XI MIA 3 was control class. The experimental class consisted 34 students 11 of them were male, and 23 of the, were female. In other hand, control class had 36 students, 14 of them were male, and 22 of them were female.

The instrument of this research was writing test of analytical exposition text. This test was very useful for this research because it measured students' writing skill. This writing text must be at least 100 words. Students had 60 minutes to do this post-test. To determine students' writing score in the post-test, the researcher used rating score in the table 3.3 below: 


\begin{tabular}{|c|c|c|c|}
\hline No & Categories & Rating Score & Classification \\
\hline \multirow{4}{*}{1.} & \multirow{4}{*}{ Organization } & $30-27$ & Excellent to good \\
\hline & & $26-22$ & Good to average \\
\hline & & $21-17$ & Average to poor \\
\hline & & $16-12$ & Poor to very poor \\
\hline \multirow{4}{*}{2.} & \multirow{4}{*}{ Content } & $20-18$ & Excellent to good \\
\hline & & $17-14$ & Good to average \\
\hline & & $13-10$ & Average to poor \\
\hline & & $9-7$ & Very poor \\
\hline \multirow{4}{*}{3.} & \multirow{4}{*}{ Vocabulary } & $20-18$ & Excellent to good \\
\hline & & $17-14$ & Good to average \\
\hline & & $13-10$ & Average to poor \\
\hline & & $9-7$ & Very poor \\
\hline \multirow{4}{*}{4.} & \multirow{4}{*}{ Language Use } & $25-22$ & Excellent to good \\
\hline & & $21-18$ & Good to average \\
\hline & & $17-11$ & Average to poor \\
\hline & & $10-5$ & Very poor \\
\hline \multirow{4}{*}{5.} & \multirow{4}{*}{ Mechanic } & 5 & Excellent to good \\
\hline & & 4 & Good to average \\
\hline & & 3 & Average to poor \\
\hline & & 2 & Very poor \\
\hline
\end{tabular}

The procedure to collect the data in conduction research will be presented in chronological order as follow:

a. Treatment. This research involved two groups given different treatments. Experimental group (XI MIA 2) was taught by using Edmodo, while the control group (XI MIA 3) was taught by using conventional teaching.

b. Test, The post-test was held to know the progression between experimental class and control class after the teacher gave treatment in experimental class, and after the teacher taught in control class without using Edmodo. In the posttest, students had to write an analytical exposition text about environment. The text must have at least 100 words. Students had 60 minutes to do this text, and collected the test to the teacher. Finally, the teacher corrected the students test and gave the students score.

The purpose of this study was to find out the effectiveness of using Edmodo in teaching writing analytical exposition text at SMAN 1 Grogol. Writing test provided the students' writing skill analytical exposition text. This data helped to know the difference result between students writing skill analytical exposition text in experimental group and control group. Before analyzing the data, the students writing skill analytical exposition text was scored based on writing test. After 
determining the score of the test, their writing skill analytical exposition text would be score based on their writing skill.

\section{RESEARCH FINDING AND DISCUSSION \\ a. The Students Writing Skill in Experimental Class}

In experimental class, posttest was conducted after the teacher gave treatment. It was in the last meeting. Before the teacher gave posttest to the students, he taught writing analytical exposition text to them by using Edmodo. By using Edmodo, teacher delivered the materials, gave the assignments, and gave feedback to each student in order to improve their writing skill. There were six meeting in this research where the first meeting was used to introduce Edmodo to the students, the second up to the fifth meeting were used to give treatment, and the last meeting was used to give post-test.

Based on the students writing skill result, it found that the highest score of experimental group was 92 and the lowest score 68 while its range was 24 . The means show in the group was 82.15 . The median was 81.50 while its mode was 80 , and the standard deviation was 6,344 . It was also found that $67,6 \%$ students got scores in interval $80-100$, whereas $32,4 \%$ got score in interval $79-66$. There was no student that had enough, less, and fail category of writing analytical exposition in experimental class

\section{b. The Students' Writing Skill in Analytical Exposition Text in Control Class}

In the control class, students' writing skill after being taught without using Edmodo is explained. Posttest was done to get the data of students' writing skill in analytical exposition text. Posttest was held after finishing the teaching of writing analytical exposition text. It was in the last meeting. Before the teacher gave posttest to the students, he taught writing analytical exposition text to them by distributing module that consisted of students' material and assessment. Teacher delivered the material in the class using Power Point presentation.

There were six meetings in control class. The first meeting was used to share the module and explain the teaching and learning process during the research. The second up to fifth meeting were to teach writing using conventional method, while in the last meeting, post-test was conducted.

Based on the students writing skill result, it found that that there are 36 students in experimental class. It shows the mean of pre-test wa 68,72 . It means that the average score of 33 students was 69 . The median score was 69,00 . The mode score was 69 , and the standard deviation was 5,795. The highest score was 82 and the lowest score was 60.

It was also found that there students who get good value with the range 80100 or categorized very good are 2 or $5,6 \%$. Then in range $66-79$ or categorized good are 22 students or $61,1 \%$, while 12 students or $33,3 \%$ are categorized fair. There was no student that has less and poor category in writing analytical exposition text in control class. From the explanation above can be concluded that in control class $5,6 \%$ students get good categorized on writing analytical exposition text. 


\section{c. The Significant Difference between Students' Writing Skill in Experimental Class and Control Class}

After finding the result of experimental and control group, the significant difference between students writing skill in experimental class and control class. Mean score of experimental class was 82,15. Mean score of control class was 68,72 . To know whether the mean difference is significant or not, the research did the calculation using SPSS 21.

Table Statistic of Difference Score Between Experimental and Control Class

\begin{tabular}{|c|c|c|c|c|c|}
\hline \multicolumn{6}{|c|}{ Group Statistics } \\
\hline & class & $\mathrm{N}$ & Mean & Std. Deviation & Std. Error Mean \\
\hline score & $\begin{array}{l}\text { experimental } \\
\text { control }\end{array}$ & $\begin{array}{l}34 \\
36\end{array}$ & $\begin{array}{l}82.15 \\
68.72\end{array}$ & $\begin{array}{l}6.344 \\
5.795\end{array}$ & $\begin{array}{l}1.088 \\
.966\end{array}$ \\
\hline
\end{tabular}

From the table above, it is shown that the result number $(\mathrm{N})$ of students in experimental class were 34. Mean score in experimental class was 82,15, its standard deviation was 6,344, and its standard error mean was 1,008 . While the number of students in control class were 36. Mean score in control class was 68,72. Its standard deviation was 5,795, and its standard error mean was 0.966 . These results indicate that the significant difference of mean value between the experimental class and the control class was found. The result if Independent Samples T-test is presented as follows:

Table of Independent Sample T-Test

\begin{tabular}{|c|c|c|c|c|c|c|c|c|c|}
\hline & \multicolumn{2}{|c|}{$\begin{array}{l}\text { Levene's } \\
\text { Test for } \\
\text { Equality of } \\
\text { Variances } \\
\end{array}$} & \multicolumn{7}{|c|}{ t-test for Equality of Means } \\
\hline & \multirow[t]{2}{*}{$\mathrm{F}$} & \multirow[t]{2}{*}{ Sig. } & \multirow[t]{2}{*}{$\mathrm{t}$} & \multirow[t]{2}{*}{ df } & \multirow[t]{2}{*}{$\begin{array}{l}\text { Sig. } \\
(2- \\
\text { tailed })\end{array}$} & \multirow[t]{2}{*}{$\begin{array}{l}\text { Mean } \\
\text { Differen } \\
\text { ce }\end{array}$} & \multirow{2}{*}{$\begin{array}{l}\text { Std. } \\
\text { Error } \\
\text { Differen } \\
\text { ce }\end{array}$} & \multicolumn{2}{|c|}{$\begin{array}{l}95 \% \text { Confidence } \\
\text { Interval of the } \\
\text { Difference }\end{array}$} \\
\hline & & & & & & & & Lower & Upper \\
\hline $\begin{array}{l}\text { Equal variances } \\
\text { assumed }\end{array}$ & .541 & .465 & 9.252 & 68 & .000 & 13.425 & 1.451 & 10.529 & 16.320 \\
\hline $\begin{array}{l}\text { Equal variances } \\
\text { not assumed }\end{array}$ & & & 9.228 & 66.540 & .000 & 13.425 & 1.455 & 10.521 & 16.329 \\
\hline
\end{tabular}

It is known that sig. (2-tailed) value was $0,000, \mathrm{t}$ value of posttest was 9,252 , degree of freedom was 68, mean difference between posttest scores in experimental and control class was 13,425 , standard error difference was 1,451, and then $95 \%$ confidence interval of the difference from the lower value was 10,529 and the upper value was 16,320. The difference of mean scores between experimental class and control class would be significant if sig. (2-tailed) value or known as $\mathrm{p}$ was lower than $0,05(a)$. Table 4.9 , shows $\mathrm{p}$ value was 0,000 . It was 
lower than 0,05 . In other word, $0,000<0,05$ or $\mathrm{p}$ value $<a$. So it can be concluded that there is significant difference between students' writing skill in experimental class and control class.

\section{d. The Effectiveness of Using Edmodo to Teach Writing Analytical Exposition Text}

To know the effectiveness of using Edmodo to teach writing analytical exposition text, independent sample t-test was used. Based on table independent T-test, it is known that $t_{\text {observed }}$ was 9,252 on the degree of freedom 68 , and $t_{\text {value }}$ in significant level 0,05 for df 68 was 1,995. As explained, Edmodo is effective to teach writing analytical exposition text if $t_{\text {observed }}$ is higher than $t_{\text {table, From the }}$ result of $t$-test, it can be seen that 9,252>1,995 or $t_{\text {observed }}$ is higher than $t_{\text {table }}$ in the significant level 5\%. It means that Edmodo is effective to be used to teach writing analytical exposition text. It accepted the alternative hypothesis $\left(\mathrm{H}_{\mathrm{a}}\right)$, and null hypothesis $\left(\mathrm{H}_{\mathrm{o}}\right)$ was rejected.

\section{CONCLUSION}

From the result of the research, it can be concluded that:

1. The students' writing skill in analytical exposition text in experimental class that being taught using Edmodo is in very good category with the mean 82,15.

2. The students' writing skill in analytical exposition text in control class that taught without using Edmodo is in good category with the mean 68,72.

3. There is significant difference of writing skill between experimental class and control class. It is proved by the significant different of mean, that is 13,43 . Besides that, $p$ value $(0,000)$ is lower than 0.05 . It means there is significant difference between students' writing skill in experiment class and control class.

4. Edmodo is effective to be used to teach writing analytical exposition text. It was proven by $\mathrm{p}$ value $(0,000)$ was lower than 0,05 . As explained, Ho would be rejected if $\mathrm{p}$ value is lower than 0.05 . So it can be concluded that Ho is rejected and $\mathrm{Ha}$ is accepted. It means Edmodo is effective to be used to teach writing analytical exposition text.

\section{BIBLIOGRAPHY}

Anggraani, M., Sofwan, A., \& Saleh, M. (2015). Improving Students' Organizing Ideas In Writing Analytical Exposition Text With Mind Mapping Technique. English Education Journal, 5(1).

Arpaci, I. (2017). The Role of Self-Efficacy in Predicting Use of Distance Education Tools and Learning Management Systems. Turkish Online Journal of Distance Education, 18(1), 52-62.

Azzahara, C., Supiatman, L. (2018). The Effect of Audio Visual Media on Students 'ability in Writing Analytical Exposition Text at Grade XI of SMKN 4 Tanjungbalai in 2017/2018 Academic Year. Jurnal Dialog, 7(1). 
Irwan, A. F., Syafei, A. F. R., \& Marlina, L. (2018). Students' Ability in Writing An Analytical Exposition Text at English Department of Universitas Negeri Padang. Journal of English Language Teaching, 7(1), 169-176.

Larasanti, S., \& Marlina, L. (2019). Using Buzz Group Technique In Teaching Writing Analytical Exposition Text for EFL Students At Senior High Schools. Journal of English Language Teaching, 8(1), 13-21.

Sari, N., Winarsih, D., \& Sarwanti, S. (2017). An Analysis of Cohesive Devices in Analytical Exposition Text Written by the Eleventh Graders of SMA N 1 Magelang in The School Year 2016/2017. Journal of Research on Applied Linguistics, Language, and Language Teaching, 1(1), 47-57.

Sumarno, W. K. (2019). Effects of Edmodo-Assisted Process Writing with the Problematized Scaffolding on the Quality of Students' Writing. Lingua Cultura, 13(1), 31-37.

Yusuf, Q., Yusuf, Y. Q., Erdiana, N., \& Pratama, A. R. (2018). Engaging With Edmodo To Teach English Writing of Narrative Texts To EFL Students. Problems of Education in the 21st Century, 76(3). 